\title{
Loading Criteria and Deposit Layer Characteristics as Causes of Sediment Settlement in an Estuary
}

\author{
Andi Patriadi ${ }^{1,2, *}$, Ria Asih Aryani Soemitro ${ }^{2, *}$, Dwa Desa Warnana ${ }^{3}$, Wasis Wardoyo ${ }^{2}$, Toshifumi Mukunoki ${ }^{4}$, \\ Gozo Tsujimoto ${ }^{4}$, Mahendra Andiek Maulana ${ }^{2}$ and Trihanyndio Rendy Satrya ${ }^{2}$
}

check for

updates

Citation: Patriadi, A.; Soemitro,

R.A.A.; Warnana, D.D.; Wardoyo, W.;

Mukunoki, T.; Tsujimoto, G.;

Maulana, M.A.; Satrya, T.R. Loading

Criteria and Deposit Layer

Characteristics as Causes of Sediment

Settlement in an Estuary. J. Mar. Sci.

Eng. 2022, 10, 27. https://doi.org/

10.3390/jmse10010027

Academic Editor: Alfredo

L. Aretxabaleta

Received: 6 October 2021

Accepted: 22 December 2021

Published: 28 December 2021

Publisher's Note: MDPI stays neutral with regard to jurisdictional claims in published maps and institutional affiliations.

Copyright: (C) 2021 by the authors. Licensee MDPI, Basel, Switzerland. This article is an open access article distributed under the terms and conditions of the Creative Commons Attribution (CC BY) license (https:// creativecommons.org/licenses/by/ $4.0 /)$.
1 Civil Engineering Department, Faculty of Engineering, UNTAG Surabaya, Surabaya 60118, Jawa Timur, Indonesia

2 Civil Engineering Department, Faculty of Civil, Planning, and Geo-Engineering, ITS, Surabaya 60111, Jawa Timur, Indonesia; wasis@ce.its.ac.id (W.W.); mahendra@ce.its.ac.id (M.A.M.); trendysatrya@its.ac.id (T.R.S.)

3 Geophysical Engineering Department, Faculty of Civil, Planning, and Geo-Engineering, ITS, Surabaya 60111, Jawa Timur, Indonesia; dwa_desa@geofisika.its.ac.id

4 Department of Civil and Environmental Engineering and Architecture, Faculty of Advanced Science and Technology, Kumamoto University, Kumamoto 860-8555, Japan; mukunoki@kumamoto-u.ac.jp (T.M.); tgozo@kumamoto-u.ac.jp (G.T.)

* Correspondence: andipatriadi@untag-sby.ac.id (A.P.); ria@ce.its.ac.id (R.A.A.S.)

\begin{abstract}
Sediment compaction due to the extraction of groundwater and self-weight consolidation, and monitoring land settlement of the river delta using geodetic measurement has been executed in several studies, while sediment settlement in the estuary is hypothesized due to dynamic loads. The present study aimed to observe clues for the occurrence of sediment settlement due to loading variation and deposit layer characteristics in the estuary. This research was based on four loading data for examination, i.e., hydraulic head pressure, sediment transport rate, sediment deposition, and water density. Two years of previous research simulations, including the rainy and dry seasons, were recalculated to gain the load pressure and were considered to assess the maximum load prediction. This review found evidence that dynamic loads predominated in maximum pressure changes in boreholes (BH2) and (BH3), and were due to river discharge and tidal occurrence, respectively. The dynamic load of sediment in $\mathrm{BH} 2$ contributed more than in $\mathrm{BH} 3$, where it was almost nonexistent. Observing the sediment layer characteristics, both settled for almost a month and two weeks, respectively, showed sediment settlement of more or less than 2 and $8 \mathrm{~mm}$. Despite insignificant loading changes, these findings can further our understanding of loading criteria and settlement in different geometric locations.
\end{abstract}

Keywords: sediment loading criteria; sediment layer characteristic; sediment settlement

\section{Introduction}

Sediment settlement in a river delta is commonly mentioned as increasing the risk of flooding due to the loss of deltaic land [1,2]. On the other hand, the appearance of deltaic land in the estuary environment is defined by the dominant influence of sediment supply that is neither transported from river flow nor from tides [3]. Before the transported sediment produces the river delta, siltation is first formed, which also has another consequence. It might obstruct fishers through the estuary pathway leading to fishing in the sea [4]. Both of these points of view describe that settlement occurs because of the consolidated sediment.

This study examined settlement in shallow estuaries with an additional load in the water column; in comparison, our previous research focused on self-weight consolidation $[2,5,6]$. The shallow estuary is deposited with sediment, which reduces the volume of the channel geometry. The load in the water column means that the river flow and tides 
act as a hydrodynamic load to consolidate the deposited sediment. Sediment deposition is invariably loaded every time, either away from water level changes due to the tides or by the height variations due to river discharge in the dry and rainy season [7]. Both are called hydraulic head fluctuation, which adjusts water pressure changes and are the reason why the bed surface sediment is gradually lowered [8]. Moreover, the water density loading and sediment transport rate in the water column are also considered contributing factors. Becker and Sultan [9] denoted that the settlement would continue and compact the sediment through time.

Several theories on the origin of land settlement accompanying compaction have been proposed. Settlement due to groundwater extraction for beach [10], domestic, and agriculture [11] infrastructure has been evaluated by monitoring geodetic measurements. Compaction due to hydrodynamics has been analyzed in the coastal area to predict settlement using numerical models $[12,13]$. The numerical model supported the development of Monte Carlo stochastic simulations and adopted hundreds of samples to simulate Holocene sediments in the river deltas [14]. Furthermore, soil consolidation theory began to be employed based on the total settlement of sediment compaction $[1,15]$. The total settlement has evolved with the use of geographic information system (GIS) analysis until recently [11-14]. The settlement stated by [2] considered the settlement only from gravity-driven self-weight, whereas [6] demonstrated that the new deposition maintained self-weight pressure.

A primary concern of the sediment settlement in this study is the repercussions of the loading variation during seasonal changes and deposit layer characteristics. There was no discussion about the loading characteristics in the estuary water column, including sediment transport, sediment deposition, water density, and hydraulic head.

\section{Materials and Methods}

\subsection{Site Locations}

In selecting the study location, the sediment process, geomorphology, and lithology sediment needed to be considered. The geological map in Figure 1 shows the downstream reach of the Bengawan Solo River. It also depicts the alluvium sedimentology in the surrounding river area. The alluvium sedimentology (yellow-plain) means the sediment material that would be transported along the river is only cobbles, pebbles, sand, clays, and local shell fragments. It could also be sourced from upstream, which does not appear on the map. However, based on the mechanism of the transported sediment, the coarse sediment soil would deposit first before entry into the estuary, then it would continue depositing fine sediment soil steadily up to the estuary.

Furthermore, another view of the sediment process was based on seasonal changes. This would affect the variations of lithology sediment (stratigraphy unit). As a fisher stated, the deposited sediment changes following the seasonal changes. The sand materials would mostly be deposited in the rainy season, and mud would be deposited in the dry season. The geomorphology on the river branch, indicated in Figure 2 (Junction A and B), shows that the characteristics of the deposited sediment would be more varied between sand and mud material. This is due to the situation of the river embankment morphology, which is perpendicular to flow from upstream and could be eroded higher and affected by the amount of sediment transport. Therefore, choosing $\mathrm{BH} 2$ and $\mathrm{BH} 3$ as borehole site locations allowed us to show the differences of stratigraphic units more clearly before and after the river branch. 

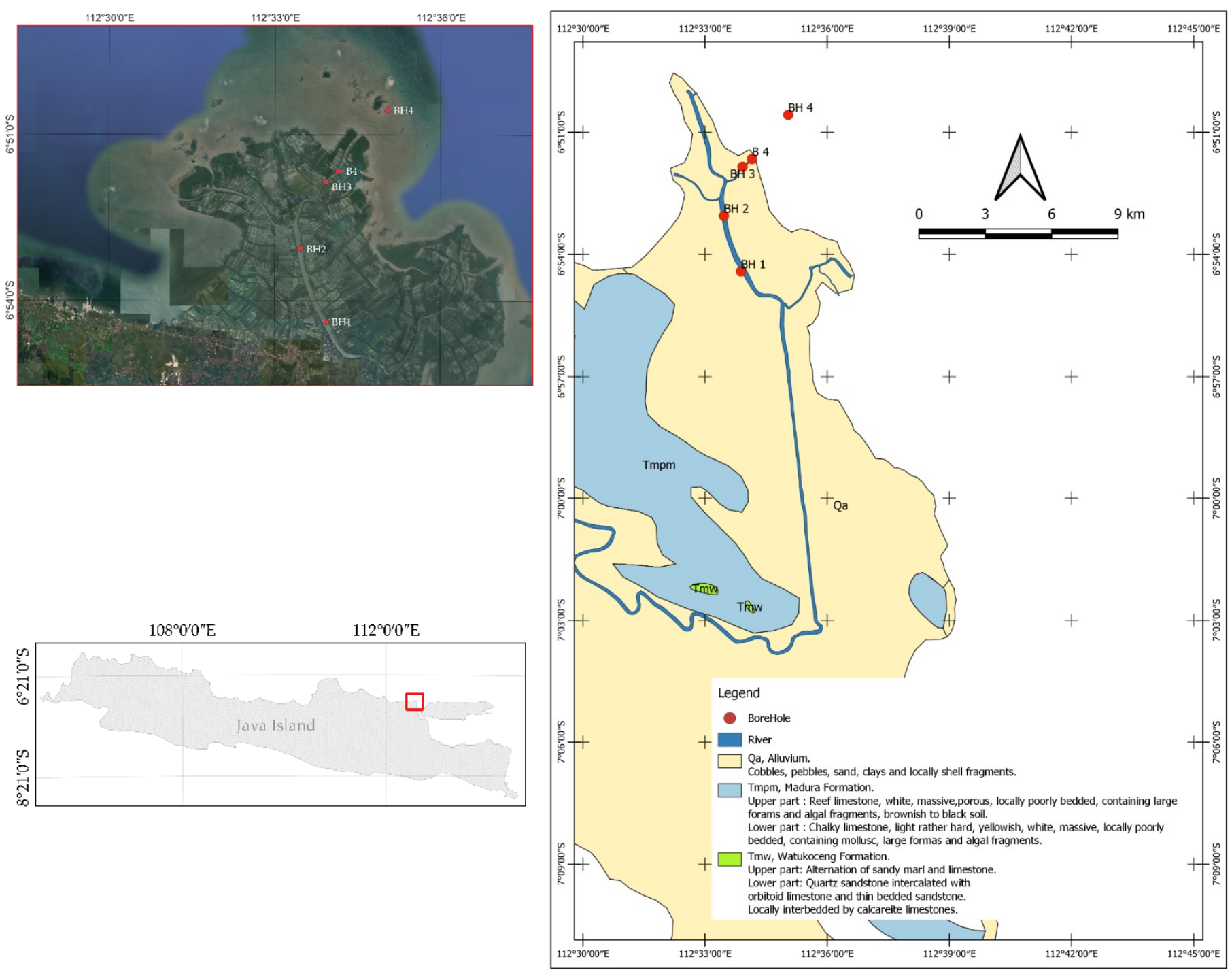

Figure 1. Geological map depicting the age of sediments. Site of borehole (BH) locations (BH1 was studied by Soemitro et al. (2020); $\mathrm{BH} 2$ and $\mathrm{BH} 3$ were studied by the authors with a different sampling method; $\mathrm{BH} 4$ followed the same sampling method as that for BH1). B4 was investigated to observe the sediment transport rate and involved $\mathrm{BH} 3$ due to its presence on the same channel (uniform flow).

\subsection{Loading Data}

Field observation and several methods followed those of the previous research in Bengawan Solo River Estuary at BH2 and BH3, Figure 1 [16]. The BH stands for borehole, which is the location for sampling sediment and load parameters. There were four kinds of load parameters for the consolidated sediment, i.e., hydraulic head pressure, sediment transport rate, sediment deposition, and water density. 


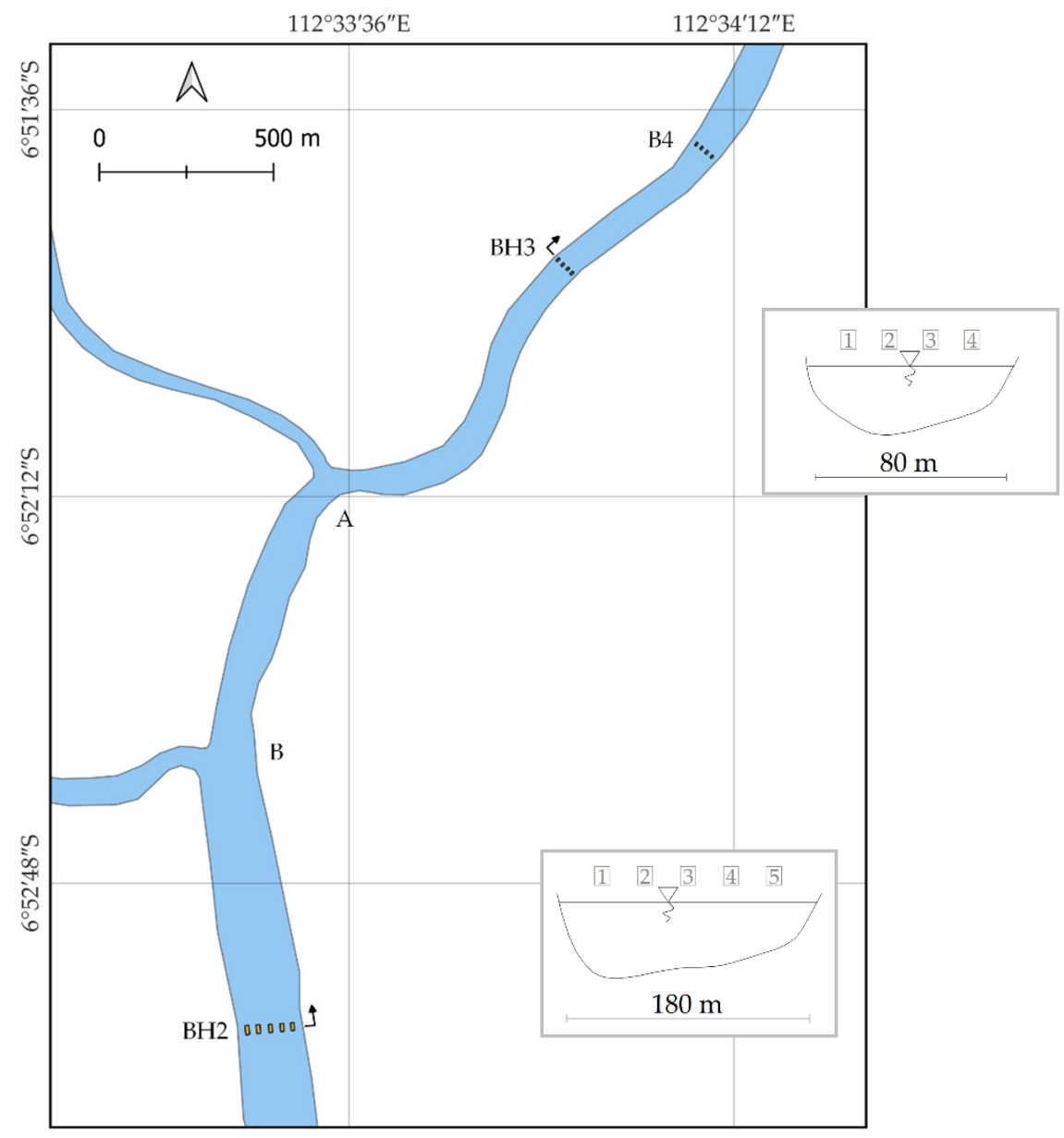

Figure 2. Column sampling of material on the river span.

The load parameter was obtained from observation and modeling and combined to determine the pressure load combination. Furthermore, the rainy and dry seasons were compared to determine which season experienced the maximum pressure load. Selecting contrasting geometry at the locations was used to compare and review the sediment settlement behavior, which was because of the hypothesis that at the end of the pressure load evaluation the load would be different at $\mathrm{BH} 2$ and $\mathrm{BH}$.

\subsubsection{Hydraulic Head Pressure}

The hydraulic head of the level unit ( $\mathrm{m}$ ) was re-examined by including the density of water to achieve the hydraulic head of the pressure unit $(\mathrm{kPa})$. It was analyzed via the HEC-RAS (Hydrologic Engineering Center-River Analysis System) software using one-dimensional unsteady flow result simulations [17]. The boundary conditions upstream and downstream were river discharge and tides. The tidal range of the higher and the lower water level was $1.41 \mathrm{~m}$. It was based on field measurement data from 6-20 November 2018 at BH1, used to validate the result simulations, with root mean square error (RMSE) of 0.9 (Figure 3). There was no wave parameter in the boundary area simulation due to wave breaking on the delta before entering the estuary. The bed roughness parameter of the river was set at 0.025 . The river has situation characteristics with no vegetation on the main and levee channels, based on Manning's value. The simulations were considered for two years before and after the Sembayat Weir was constructed. The time-step for the detailed output interval was set at one hour. The pressure was considered based on the difference of water level changes shown in Figure 4. When the present water level was lower than that of the following period, it indicated a load addition. On the contrary, there was no load reduction if the following period was lower than the current water level. 
Commonly, a water level that becomes lower indicates that the hydrostatic pressure also decreases. However, the behavior of continuously flowing water, always bringing and eroding sediment, was assumed as producing a constant load. This was due to the erosion process being considered as supplying axial and lateral force to the riverbed.

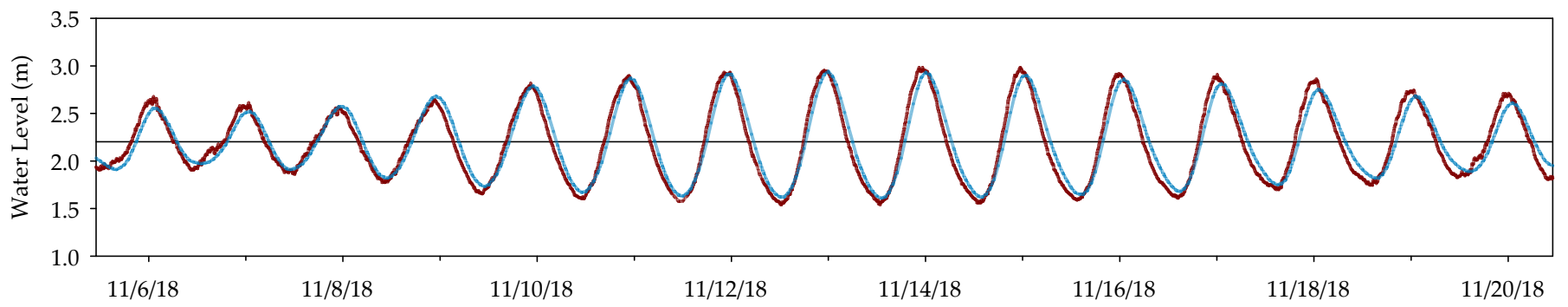

Figure 3. Validation of the simulation results at BH1 (red and blue line represent field measurement and simulation data, repectively).

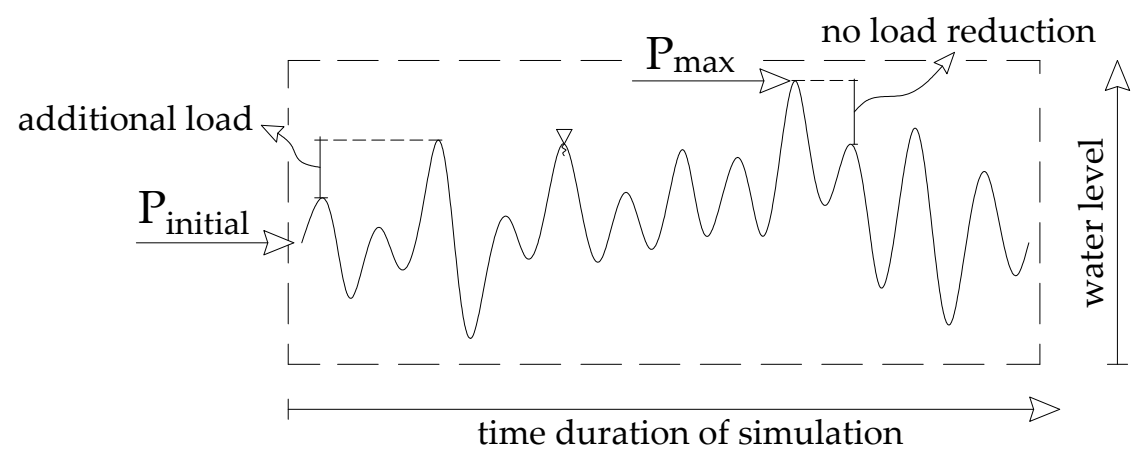

Figure 4. Loading scheme of hydraulic head pressure and continuous flow.

\subsubsection{Sediment Transport Rate}

HEC-RAS did not simulate the sediment transport rate because it does not support the suspended sediment concentration (SSC) as an input parameter. Another method has been conducted by [18] using an artificial neural network (ANN) to understand the behavior of SSC in the estuary. However, this study carried out a simplified method for assessing the transport rate by taking sample material for each month and processing it into a power equation formula to predict SSC during the same period with the hydraulic head parameter. There was no measurement of turbidity. The sediment transport rate was controlled by the outflow discharge and the tidal pumping. This specific data observation is not yet published, and the sampling material follows the previous study [16].

\subsubsection{Sediment Deposition}

Determining sediment deposition depends on the sediment transport rate that runs in or out along the flow course conducted by point controlling at B4. Based on the principle of the continuity equation, the discharge of a steady flow is uniform along the channel [19]. Therefore, the amount of sediment transport in suspension was controlled in the BH3-B4 river segment area with a distance of $550 \mathrm{~m}$ (Figure 2). Handling was also included in the flow velocity. They were measured within four water columns for each cross-section and consisted of a three-point observation in any depth (h) of the water column $(0.2,0.6$, and $0.8 \mathrm{~h}$ ) to observe the spread of material. The suspended sediment and flow velocity were taken using a bottle water sampler and an electromagnetic current meter (Marsh Mc Birney Model 21 series; manufactured by Hach Company, Loveland, CO, USA). The limitation of this observation was that sampling took place at different times, and the column (point) sampling was also changed (Figure 2). Therefore, the cross-section of each month's sampling location constantly changed because fishers did not permit the installation of stakes on the riverway, which otherwise may have been measured precisely. This was carried out via moving the water column from site to site to obtain a cross-section 
from upstream to downstream by fisher boat. The time gap was two hours adjacent to the cross-section. This approach made it possible to represent the sampling material simultaneously as consideration of flow velocity was still relatively constant. It was also supported by the diurnal tides when the data collection was conducted at noon.

\subsubsection{Water Density}

The density of water occurring in the estuary consists of freshwater $\rho_{w}$ and seawater $\rho$. Determining the water content of seawater or freshwater was conducted using a water quality tester (Constant WT61, manufactured by Constant Instruments, Joondalup, Australia). It was tested after sampling suspended sediment by a bottle sampler on the boat. Figure 5 illustrates the salinity contour data processed in SURFER 2D software on the cross-section of BH2. The salinity was well mixed except during July 2017. It could be possible due to the transition from ebb to flood or contrariwise, following the water sampling. This exchange phenomenon representing the tidal condition was stratified flow. The salinity results shown in Table 1 are the average data for the 0.8 depth (h) of each water column. Choosing $0.8 \mathrm{~h}$ was due to the higher turbidity or sediment concentration attainable close to the riverbed.

Table 1. Data measurement of water physics in the Bengawan Solo River estuary.

\begin{tabular}{ccccccc}
\hline \multicolumn{2}{c}{ BH2 } & \multicolumn{3}{c}{ BH3 } \\
\hline Sampling Time & $\begin{array}{c}\boldsymbol{\rho} \\
\left(\mathbf{k g} / \mathbf{m}^{\mathbf{3}}\right)\end{array}$ & $\begin{array}{c}\text { Salinity } \\
(\mathbf{p p t})\end{array}$ & $\begin{array}{c}\text { Temperature } \\
\left({ }^{\circ} \mathbf{C}\right)\end{array}$ & $\begin{array}{c}\boldsymbol{\rho} \\
\left(\mathbf{k g} / \mathbf{m}^{3}\right)\end{array}$ & $\begin{array}{c}\text { Salinity } \\
(\mathbf{p p t})\end{array}$ & $\begin{array}{c}\text { Temperature } \\
\left({ }^{\circ} \mathbf{C}\right)\end{array}$ \\
\hline October 2016 & 996.09 & 0.13 & 28.84 & 996.11 & 0.23 & 29.05 \\
\hline November 2016 & 996.57 & 0.50 & 28.17 & 996.57 & 0.51 & 28.18 \\
\hline December 2016 & 996.14 & 0.14 & 28.72 & 995.98 & 0.15 & 29.28 \\
\hline January 2017 & 996.03 & 0.19 & 29.22 & 995.46 & 0.20 & 31.10 \\
\hline February 2017 & 996.21 & 0.21 & 28.62 & 996.28 & 0.20 & 28.40 \\
\hline March 2017 & 995.79 & 0.28 & 30.22 & 995.96 & 0.27 & 29.65 \\
\hline April 2017 & 996.23 & 0.17 & 28.48 & 996.08 & 0.16 & 28.95 \\
\hline May 2017 & 996.18 & 0.80 & 30.22 & 1001.84 & 8.54 & 30.53 \\
\hline June 2017 & 996.51 & 0.63 & 28.68 & 1000.71 & 6.36 & 28.95 \\
\hline July 2017 & 1001.77 & 7.70 & 28.74 & 1001.42 & 7.40 & 29.15 \\
\hline August 2017 & 1002.46 & 8.47 & 28.36 & 1002.64 & 8.91 & 28.85 \\
\hline September 2017 & 1002.49 & 8.90 & 29.30 & 1002.21 & 8.95 & 30.33 \\
\hline
\end{tabular}

The water density is calculated based on equation states [20] from data on temperature $t$ and salinity $S$. The equation for $\rho$ was obtained from the calculation of the density of freshwater $\rho_{w}$ (salinity $=0$ ) as follows:

$$
\begin{gathered}
\rho_{w}=999.842594+6.793952 \times 10^{-2} t-9.095290 \times 10^{-3} t^{2}+1.001685 \times 10^{-4} t^{3} \\
-1.120083 \times 10^{-6} t^{4}+6.536332 \times 10^{-9} t^{5}
\end{gathered}
$$

Seawater $\rho$ was then calculated as follows:

$$
\begin{aligned}
\rho(S, t, 0)=\rho_{w}+\quad & S\left(0.824493-4.0899 \times 10^{-3} t+7.6438 \times 10^{-5} t^{2}\right. \\
& \left.-8.2467 \times 10^{-7} t^{3}+5.3875 \times 10^{-9} t^{4}\right) \\
& +S^{3 / 2}\left(-5.72466 \times 10^{-3}+1.0227 \times 10^{-6} t^{2}\right) \\
& +4.8314 \times 10^{-4} S^{2}
\end{aligned}
$$




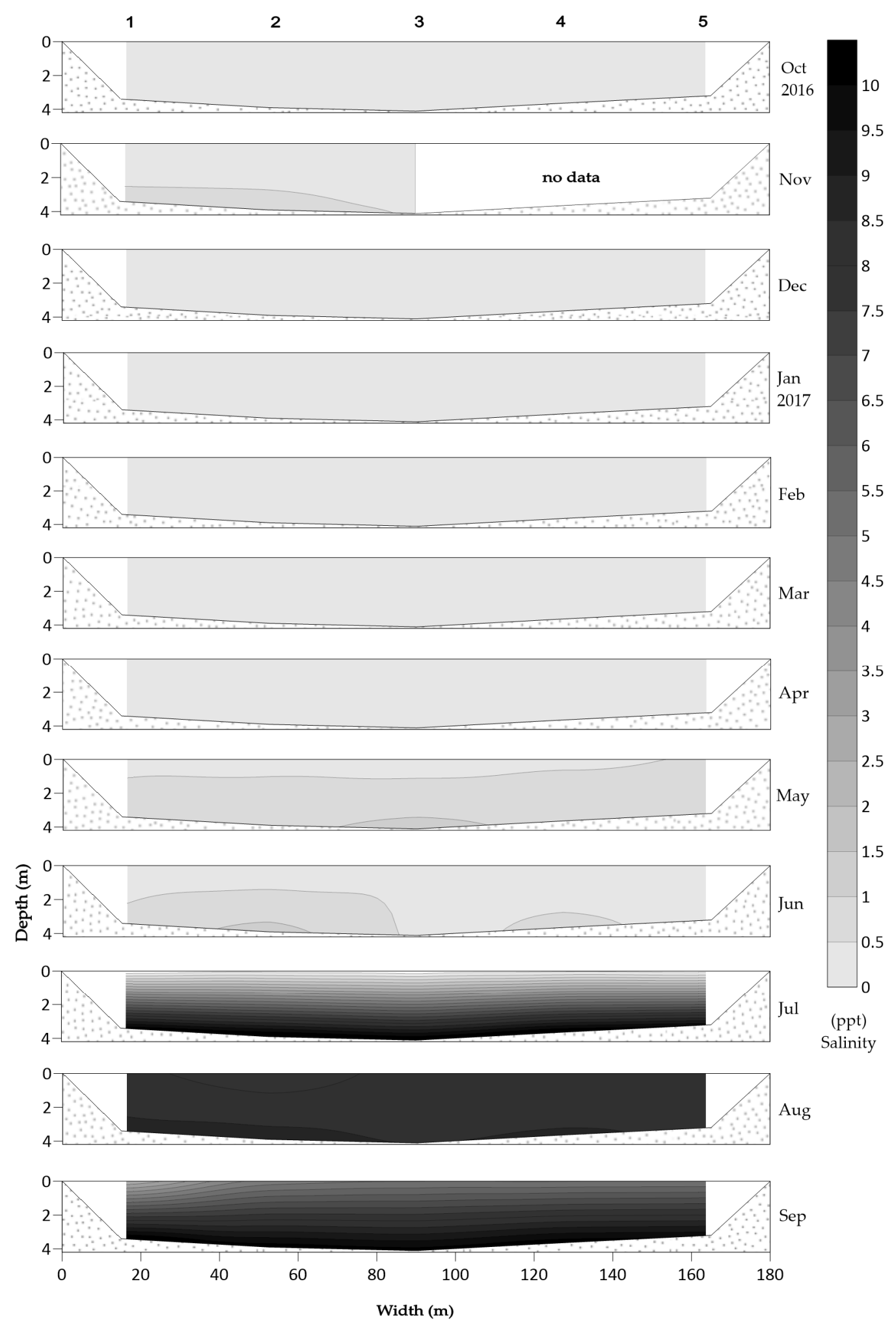

Figure 5. The cross-section of salinity contour data at $\mathrm{BH} 2$.

\subsection{Observation Methods}

The consolidated sediment is the preserved fluvial deposit subsequently burdened by the load on it (water column). The fluvial deposit (sedimentology) had various sediment lithology, which depended on the types of transported and settled sediment at that moment [21]. As claimed by the fishers, the fluvial deposits transform consistently with seasonal changes. In engineering practice, lithologic characteristics of fluvial soil deposits 
are divided into sand, silt, and clay [6]. Determination of sediment lithology used for grain-size analysis followed the American Society for Testing and Materials (ASTM) D6913 standard. In this study, silt and clay were categorized as a soft sediment layer.

Regarding the sediment consolidation phenomenon, an oedometer test was authorized as appropriate for the one-dimensional Terzaghi's consolidation model [22]. We had no consolidation model to validate the settlement in the field. In observational studies, the sediment depositions at $\mathrm{BH} 2$ and $\mathrm{BH} 3$ were drilled until $-5 \mathrm{~m}$ from the bed surface. The selection of $\mathrm{BH} 2$ and $\mathrm{BH} 3$ was due to considering the geomorphological process (erosiontransport-deposit) [23] that was triggered at the river branch and affected the sediment transport rate among junctions A and B. Furthermore, the drilled depositions of $-5 \mathrm{~m}$ were assumed since the thickness could already represent lithologic data. The lithology of the depositional environment in the upper and lower delta plain (subaerial delta) [3] consists of silty sand and clayey silt [2]. It was determined by using a thin-walled tube sampler appropriate for the ASTM D1587 procedure and observed in the Laboratory of Soil Mechanics and Rocks (ITS Surabaya). The consolidation test was based on ASTM D4235-04 and set up $2 \mathrm{~cm}$ high and with a $6.5 \mathrm{~cm}$ diameter in saturated conditions. The loading increment in the laboratory was unlike the field loading behavior. However, the void ratio changes and compressibility coefficient were used for calculating the final settlement, $\mathrm{S}$, using the equation below [24]:

$$
\begin{gathered}
S=S_{1}+S_{2}+S_{3}+\ldots \ldots+S_{n}=\sum_{i=1}^{n} S_{i} \\
S_{i}=\frac{\alpha_{i} \times \Delta p_{i} \times h_{i}}{\left(1+e_{0 i}\right)}
\end{gathered}
$$

where $S_{i}$ is the compaction for each layer in $\mathrm{mm}$, $\mathrm{i}$ is the total number of stratigraphic layers, $\alpha_{\mathrm{i}}$ is the compressibility coefficient of each layer in $\mathrm{MPa}^{-1}, \Delta \mathrm{p}_{\mathrm{i}}$ is the pressure from the total number of loading data, $\mathrm{h}_{\mathrm{i}}$ is the thickness of each layer in $\mathrm{m}$, and $\mathrm{e}_{0 \mathrm{i}}$ and $\mathrm{e}_{i}$ are the initial and final void ratio of the laboratory test.

To identify the time duration from initial to final settlement, this study only used primary consolidation and the time corresponding to the particulars of consolidation using $\mathrm{t}_{100}\left(100 \%\right.$ consolidation). The criteria for selecting the time factor $\mathrm{T}_{\mathrm{v}}$ against the degree of consolidation $\mathrm{U} \%$ follow [22]:

$$
\begin{aligned}
& \mathrm{T}_{\mathrm{V}}=\frac{\pi}{4}\left(\frac{\mathrm{U} \%}{100}\right)^{2} \\
& \mathrm{C}_{\mathrm{v}}=\frac{\mathrm{T}_{\mathrm{v}} \mathrm{H}_{\mathrm{d}}{ }^{2}}{\mathrm{t}_{50}}
\end{aligned}
$$

where $\mathrm{H}_{\mathrm{d}}$ is the length of the drainage path, which is half the specimen height at the appropriate increment or double-sided drainage.

\section{Results}

\subsection{Characteristics of Sediment Transport Load}

The suspended sediment concentration (SSC) was evaluated as a feature of sediment transport load and correlated against flow velocity, as shown in Figure 6a,b. It is the plot of instantaneous profiles. Please note that there are no data for observations of water flow direction or particle size distribution of sediment transport. The performance results of flow velocity during the rainy seasons (October 2016-April 2017) did not show a uniform sediment transport rate. The results, as shown for November, February, and April, indicate the maximum velocity conditions at $\mathrm{BH} 2$. However, the amount of sediment transport in February was a one-third smaller than in November and April. In February, rhythm inequivalent was possible because the gate operating system at Sembayat Weir closed the gate. Overall, the discharge was not significant, i.e., $578 \mathrm{~m}^{3} / \mathrm{s}$ in November, $613 \mathrm{~m}^{3} / \mathrm{s}$ in February, and $617 \mathrm{~m}^{3} / \mathrm{s}$ in April (Figure 7). 

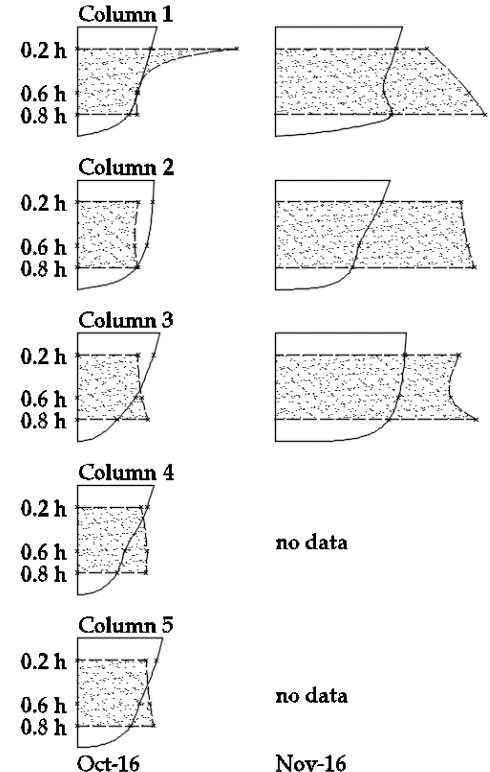

no data
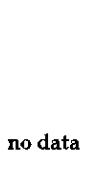

Nov-16 flow velocity $: 0 \longrightarrow 1 \mathrm{~m} / \mathrm{s} \quad \mathrm{SSC}: 0 \longrightarrow 1 \mathrm{~kg} / \mathrm{m}^{3}$
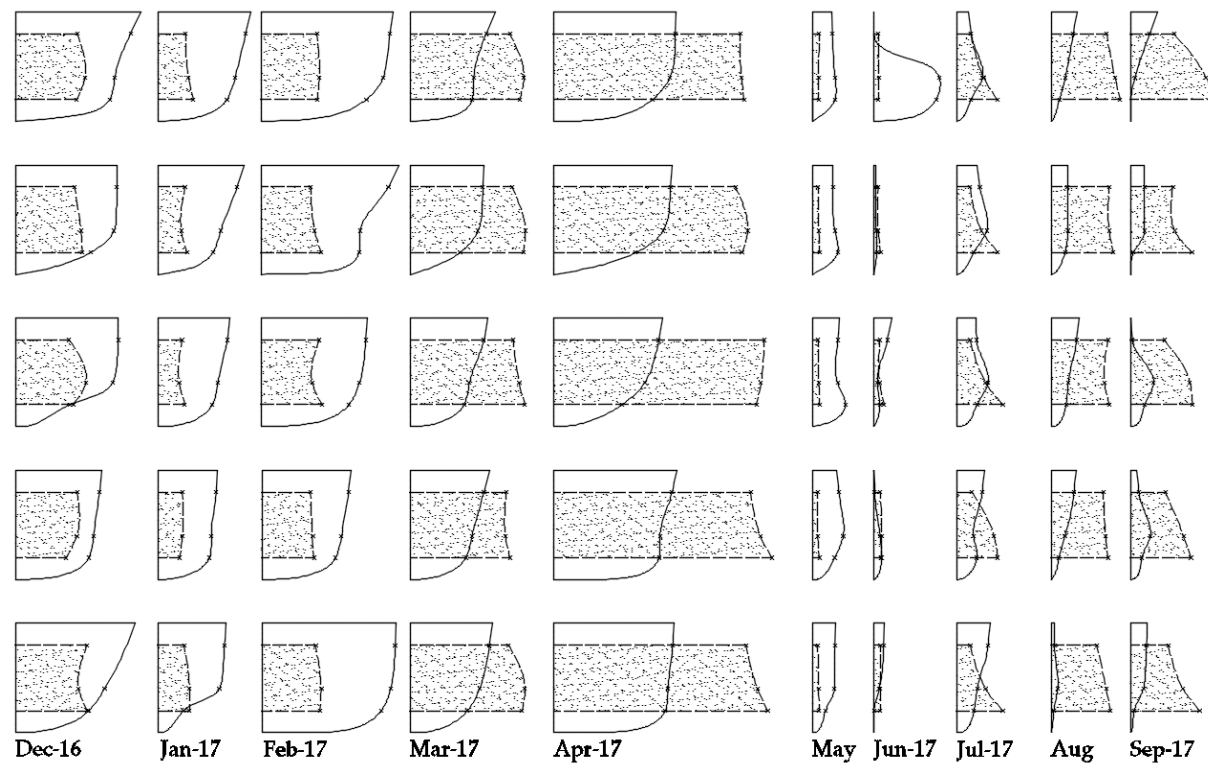

a

flow velocity $: 0 \longrightarrow 1 \mathrm{~m} / \mathrm{s} \quad S S C: 0 \longrightarrow 1 \mathrm{~kg} / \mathrm{m}^{3}$
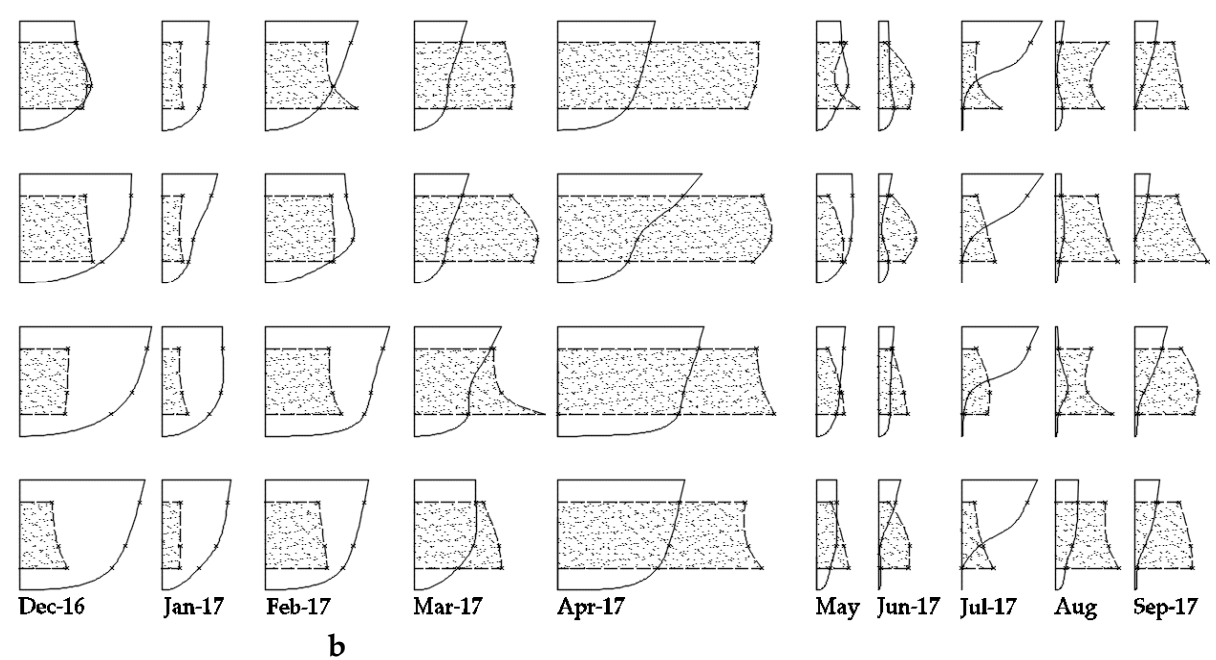

Figure 6. Correlation between SSC and flow velocity at $\mathrm{BH} 2(\mathbf{a})$ and $\mathrm{BH} 3(\mathbf{b})$.

Ji et al. [25] proved that some types of sediment transport were simulated based on the flood hydrograph at Nakdong River Estuary Barrage. Observing BH3, the sediment transport rate also varied during the rainy season. In November, the expressive tendency of the sediment transport rates was caused by vulnerable erosion at the river branch and supported by the high flow velocity, except on column 1. It was located beyond the inner bend of the river, which slightly curved when observed spatially. In contrast, the slower flow velocity in the dry season (May-September 2017) showed a higher sediment transport rate in July-September at BH2. Two months of sediment transport, in May and June, were smaller because the saline content at the location had not intruded at that time when sampling (Table 1). 


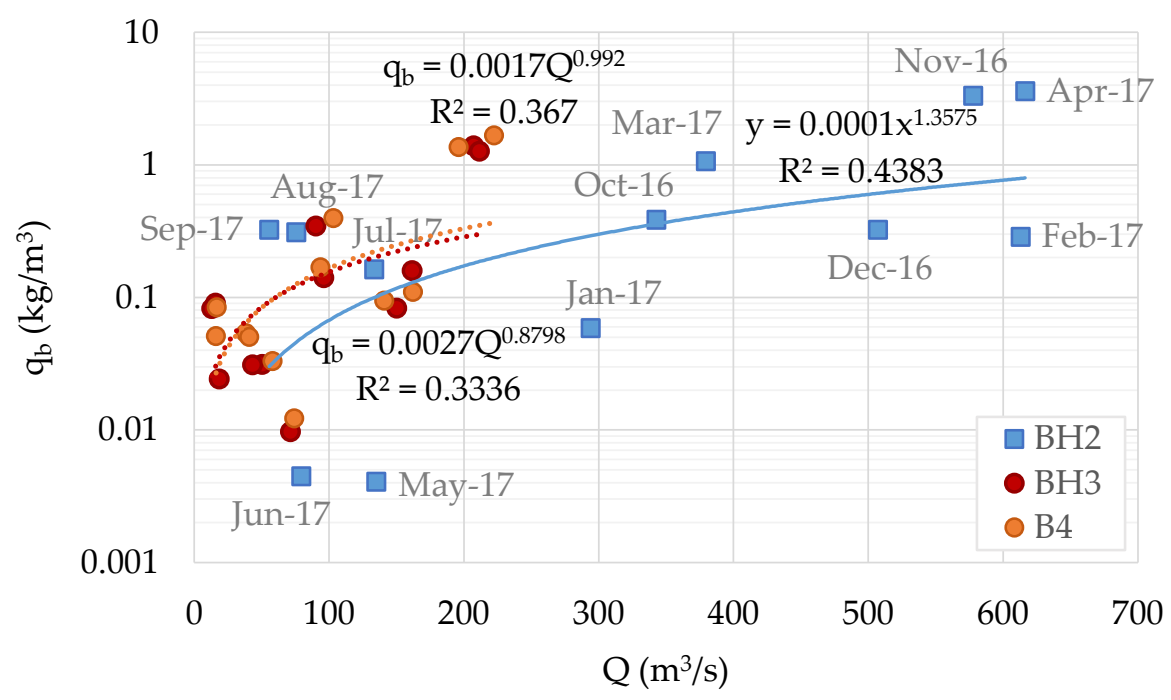

Figure 7. Sediment transport rate and flow discharge relation.

Furthermore, $\mathrm{BH} 3$ produced a sediment transport rate throughout the dry season. A more simplified characteristic of the sediment transport rate is displayed in Figure 8. These results suggest that $\mathrm{BH} 3$ received more sediment transport load in the rainy season. Narrowing and shallowing of channel geometry at $\mathrm{BH} 3$ could also be a reason for increased bottom shear stress due to current flow and resulted in a higher sediment transport rate. On the other hand, the flood current in the rainy season was a powerful contributor to flushing the deposited sediment when the Sembayat Weir opened (Figure 1) within the area. This would reduce the sediment transport rate at $\mathrm{BH} 2$ and $\mathrm{BH} 3$ if the gate closed during the dry season. Nonetheless, the tidal current has a role in eroding the sediments around $\mathrm{BH} 3$ [18].

\subsection{Sediment Deposition Correlation}

The maximum sediment transport load at $\mathrm{BH} 2$ and $\mathrm{BH} 3$ in the rainy season was around $2-2.5 \mathrm{~kg} / \mathrm{m}^{3}$ in November 2016 and April 2017, while during the dry season, August-September 2017, it was $1 \mathrm{~kg} / \mathrm{m}^{3}$. Figure 9 compares sediment transport load (in the form of suspended sediment concentration) and flow velocity from BH3 to B4 in the dry season. Both segments were considered to have similar physical and kinematical characteristics, proven by the discharge similarity (Figure 7). The dry season was chosen since quiet water frequencies in the tidal regime occurred often. The quiet water occurred due to the switchover in the transition from ebb to flood or vice versa. The concept of mud sedimentation in the estuary, including flocculation, hindered permeability, and effective stress was divided based on mass concentration: suspended, fluid mud, recently deposited, and settled [26]. Hence, this study assumed that suspended sediment would settle and deposit in the case of the submerged weight of the sediment grain or flocculation being larger than the drag force. Furthermore, the flow velocity distribution at the bottom (friction velocity) would erode the bed sediment material along the BH3-B4 segment area, which is beyond the area of quiet water. 


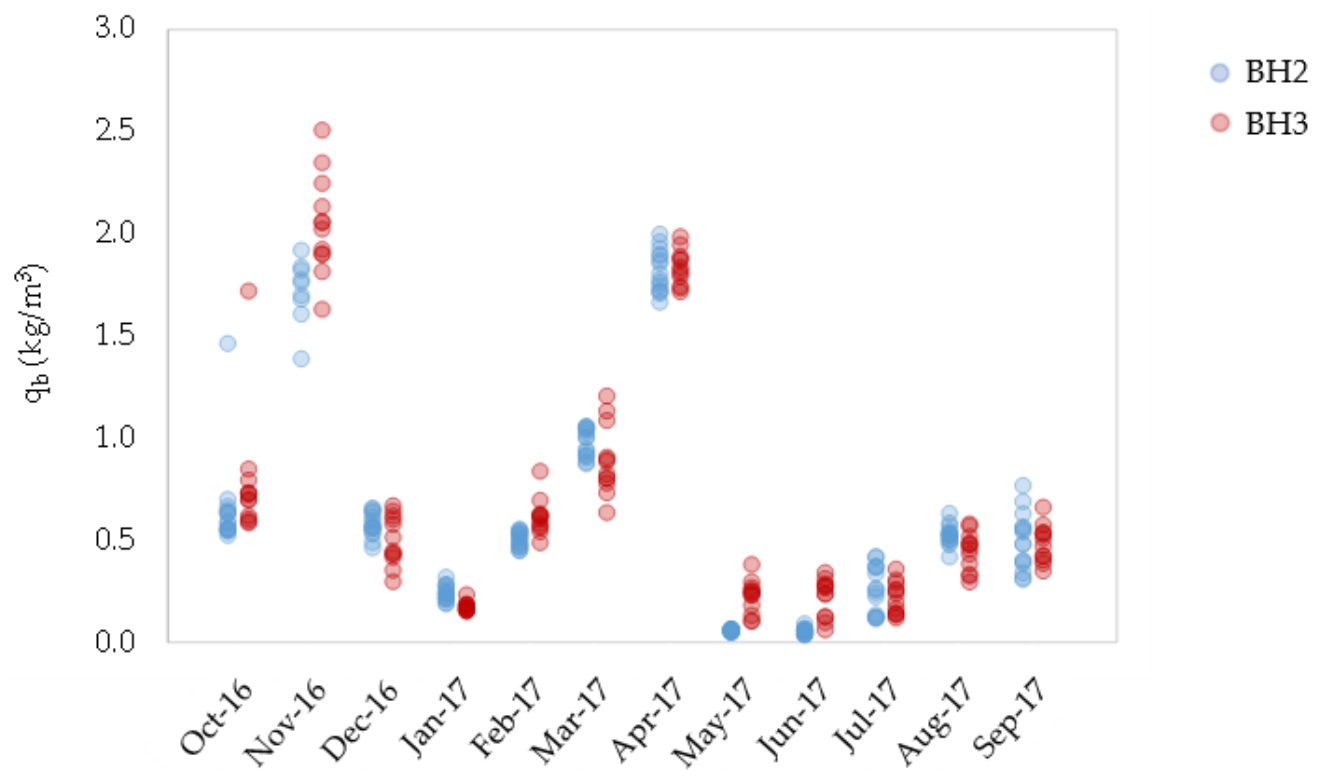

Figure 8. Comparison of sediment transport rates at $\mathrm{BH} 2$ and $\mathrm{BH} 3$ in one year of sampling sediment.

Quantitatively, the results denote the SSC among the inflow and outflow in June and August 2017, demonstrating the sediment equilibrium on erosion and deposition. This result justifies the argument of complexity, taking into account sediment deposit accumulation [6]. Therefore, the variation in the ground level changes is not discussed because the method does not work effectively to determine sediment deposition accuracy.
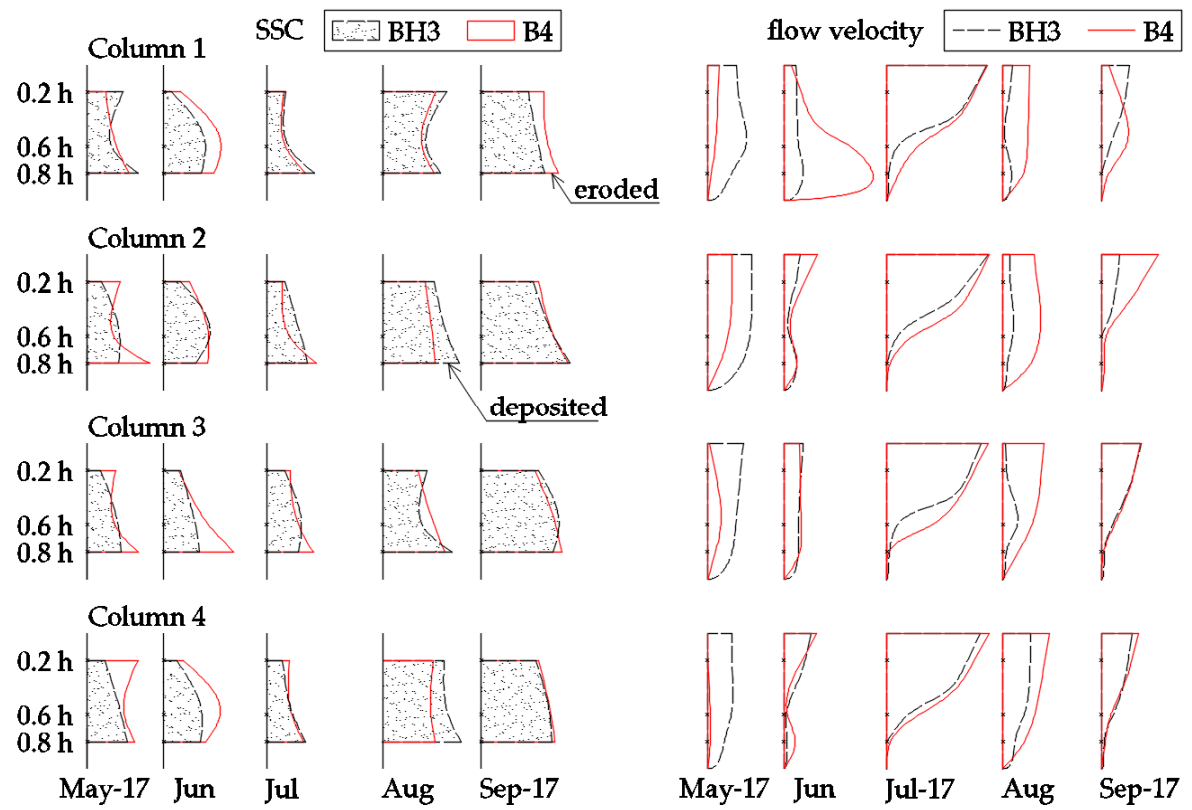

Figure 9. Sediment transport load and flow velocity in the BH3-B4 segment area.

\subsection{Fresh and Saline Water}

As shown in Table 1, the fresh and saline water prove the water density according to the specific formulation stated in Section 2.2.4. There was no significant change in the results of measurement between 996 and $1002.5 \mathrm{~kg} / \mathrm{m}^{3}$ of data. Likewise, the water temperature was in the range of $28.17^{\circ}-31.10^{\circ}$. The low salinity levels, which vary between 0.1 and 0.8 ppt at $\mathrm{BH} 2$ and $\mathrm{BH} 3$, were influenced by the rainy seasons (October 2016-April 2017) because of continuous flowing river discharge; thus, the seawater could not counter the river flow. In comparison, high salinity, between 6-9 ppt, occurred in the dry season 
between May 2017 and September 2017. However, there was a two-sample discrepancy in salinity of the water in May and June at BH3. This was due to the time of water sampling. The seawater condition began to enter the river channel, and the saline water had not reached $\mathrm{BH} 2$. The presence of saline water indicated it was still flowing at $\mathrm{BH}$. It is even possible that the opposite phenomenon could occur: the water started to flow from $\mathrm{BH} 2$ to $\mathrm{BH} 3$. Based on the field observation, it is necessary to know that the receding of seawater is faster than the entrance of seawater to the river when Sembayat Weir is closed.

\subsection{Pressure Load Combination}

Observing Figure 10, the maximum sediment transport rate contributed approximately $0.38-0.62 \mathrm{~kg} / \mathrm{m}^{3}$ and $0.15-0.27 \mathrm{~kg} / \mathrm{m}^{3}$ at $\mathrm{BH} 2$ and $\mathrm{BH} 3$, respectively. Furthermore, the water density was only taken into account in the dry season because the salinity was higher and supplied more pressure (Table 1). The next loading result of the survey was concerned with the water level changes for each water column situation on the $\mathrm{BH} 2$ and BH3 cross-section (Figure 11). Based on the criteria, variation in the depth of the water presented a load of each water column that was also different. Therefore, the sediment settlement was represented in $1 \mathrm{~m}^{2}$ of the bed surface area in the middle of the river section and adjusted to the borehole site location.

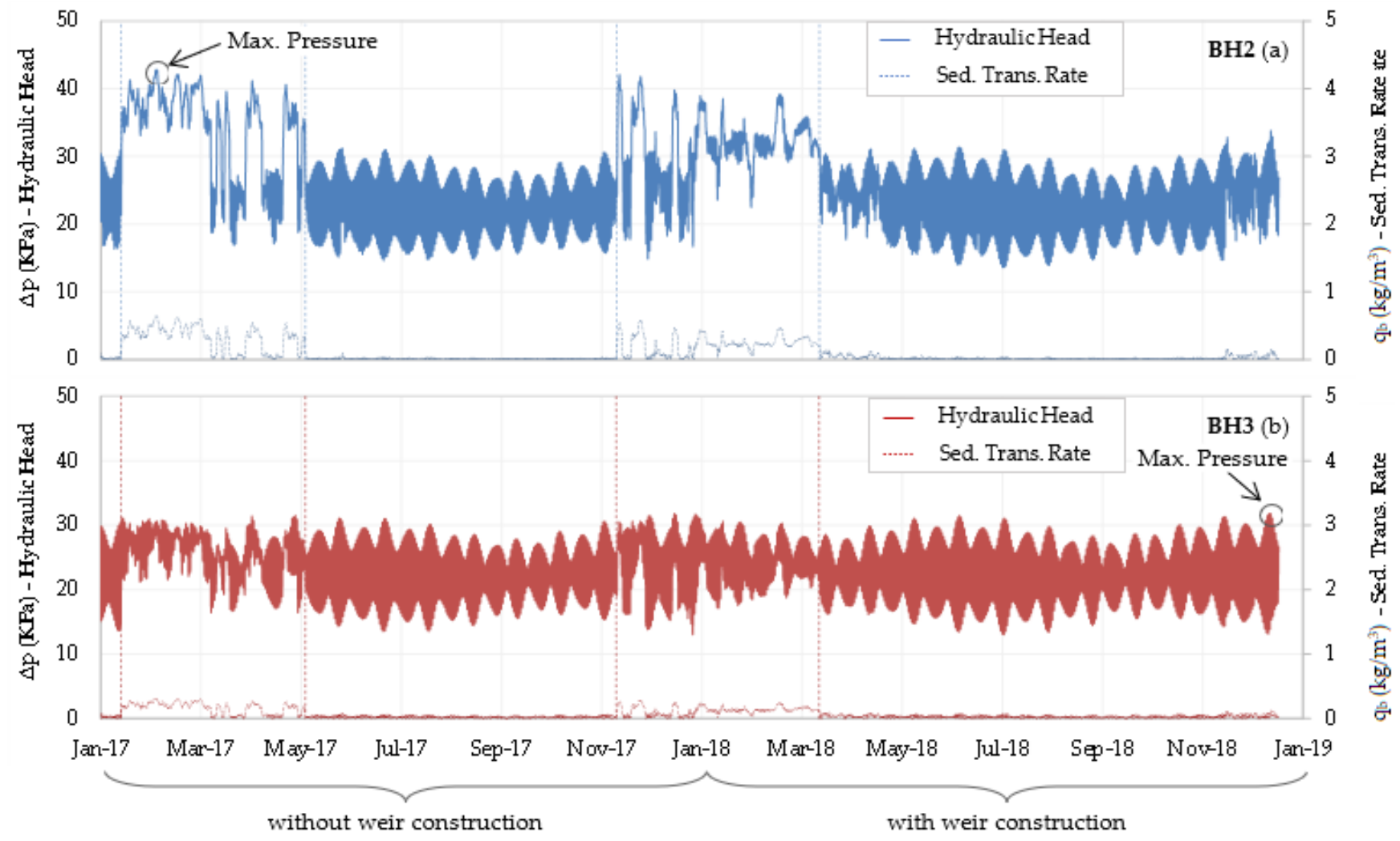

Figure 10. Loading condition by hydraulic head (left y-axis) and sediment transport rate (right y-axis) at $\mathrm{BH} 2(\mathbf{a})$ and $\mathrm{BH} 3(\mathbf{b})$. 


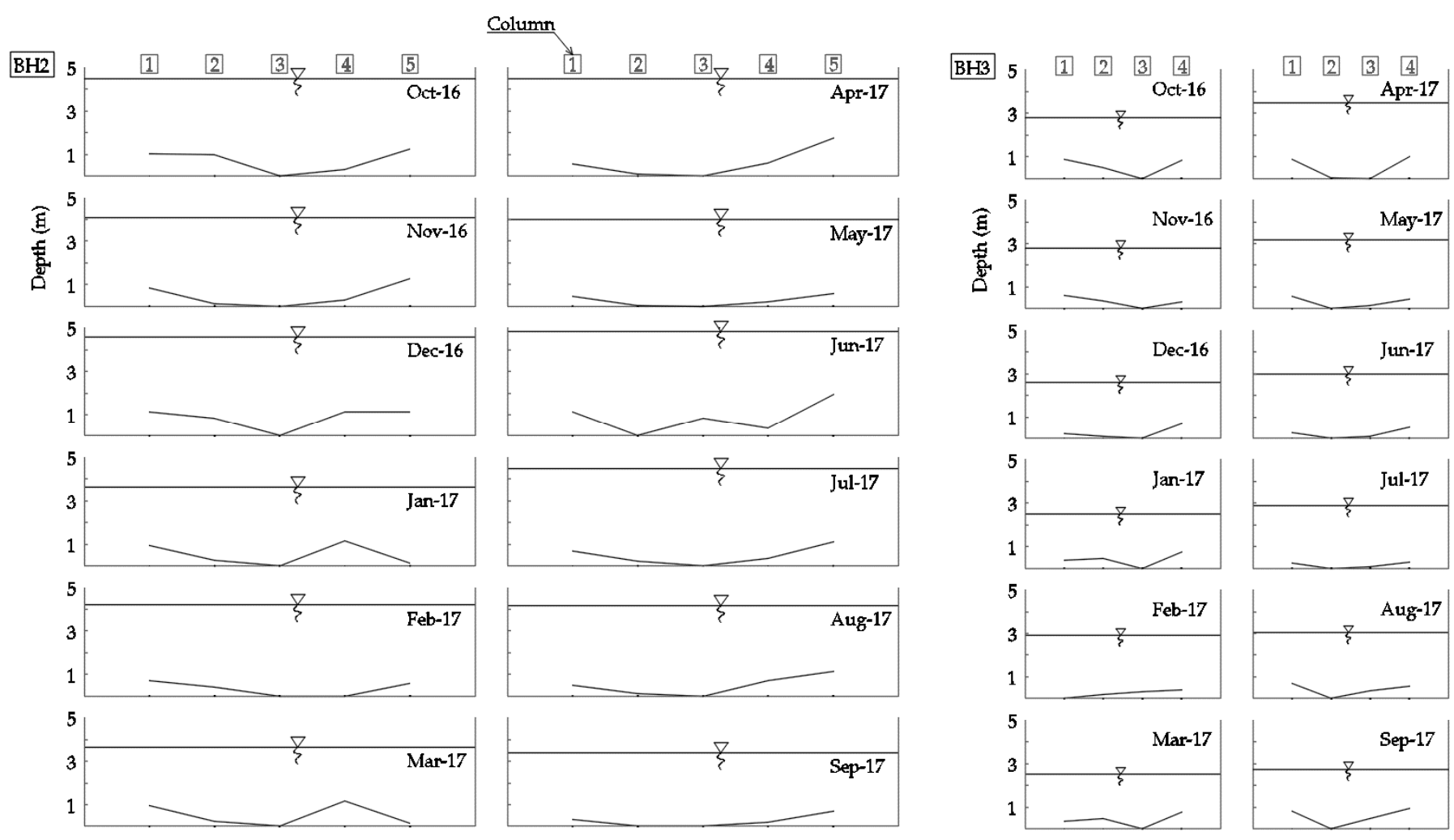

Figure 11. Cross-section of $\mathrm{BH} 2$ and $\mathrm{BH} 3$ with variations of the water depth on each column.

In consolidation theory, the sediment had undergone an overburden of pressure through time. Referring to Section 2.2.1, overburden pressure is assumed in the process of water level fluctuation that has not yet appeared, and the present maximum pressure displayed in Figure 10a,b may have occurred in the past. The maximum hydraulic head pressure of $\mathrm{BH} 2$ was $42.77 \mathrm{kPa}$ in the prior rainy season before Sembayat Weir was constructed; while $\mathrm{BH} 3$ was $31.81 \mathrm{kPa}$ which occurred in the transition of dry to rainy season after Sembayat Weir was constructed. Owing to a lack of historical data, the hydrostatic pressure condition applying to the tidal-dominant water region had significant water level changes during the dry season, resulting in the changes for SSC becoming higher. Therefore, a load occurs at that moment. High load pressure at $\mathrm{BH} 2$ was influenced by channel geometry, becoming narrow at the river branch, and the Sembayat Weir did not exist at that time. Therefore, there was a flux flow, while the flood or ebb tide caused the water level to become higher. Considering BH3, a high-pressure load took place after the weir was built, and the last simulation was higher than the previous one.

\subsection{Sediment Layer}

The sediment grain distribution, shown in Figure 12, compared the layer characteristics of the Bengawan Solo River estuary. There are five and fifteen layers of silt and clay in the consolidation model at $\mathrm{BH} 2$ and $\mathrm{BH} 3$, respectively. The sand was considered settling immediately due to the porous material. This was a different method of taking the sample material. Analysis of BH1, conducted by Soemitro et al. [27], used the same method as applied to BH4, i.e., the sampling sediments were taken at the depths of 1,3 , and $5 \mathrm{~m}$. This method did not detail sediment parameters to review the settlement behavior on the shallow drill core (five meters). Furthermore, $\mathrm{BH} 1$ and $\mathrm{BH} 2$ showed significant sediment grain distribution at the -2 to -3 layer with a distance of only $2.5 \mathrm{~km}$, invariable in river span. The expression was probably caused by the high performance of the hydrodynamic conditions at $\mathrm{BH} 2$ related to the close proximity to the river morphology (branch geometry). 


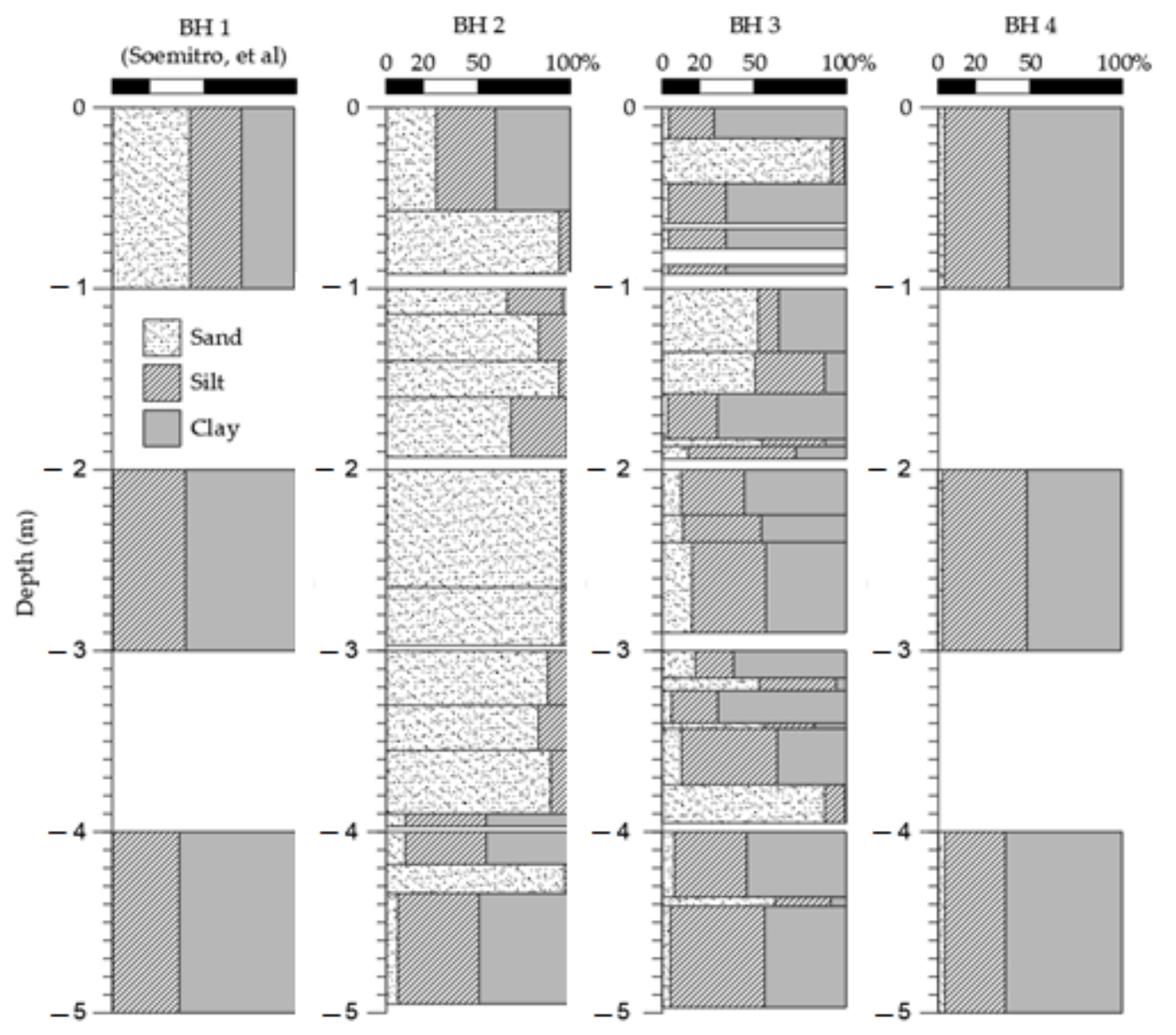

Figure 12. Stratigraphy of sediment grain distribution.

\section{Discussion}

An initial objective of this research was to identify clues to the occurrence of sediment settlement. This study found that various loading types did not contribute much to settling of the sediment bed surface. It showed a discrepancy in the occurrence of the hypothesized condition in the estuary. An observation against sediment layer characteristics that were studied in the river delta (Figure 13a) was compared to sediment under loading water in this research (Figure 13b). The findings confirmed the total time of primary consolidation, and the dots in both graphs denote a 100\% degree of consolidation. $\mathrm{BH} 2$ and $\mathrm{BH} 3$ settled for almost a month and two weeks, respectively, for settlements of more or less than 2 and $8 \mathrm{~mm}$. This indicated that the sediment deposit underwater settled rapidly, but settlement was small.

In comparison to the river delta, Zhang et al. [2] estimated 37 years for $23 \mathrm{~cm}$ sediment settlement, while Liu et al. [6] estimated 18 years for $48 \mathrm{~cm}$. This shows the significance gap. Indeed, the thickness of soft layers was 1.57 and $3.68 \mathrm{~m}$ for $\mathrm{BH} 2$ and $\mathrm{BH} 3$, and 9 and $10 \mathrm{~m}$ for Zhang et al. [2] and Liu et al. [6], respectively. By adopting BH2 and BH3, the differences in sediment distribution characteristics for accumulating the compaction can be understood, as shown in Figure 14. The sediment characteristics affecting the settlement at $\mathrm{BH} 2$ were because the sand distribution was greater than that of soft soils. The void ratio and compressibility coefficient of each layer also affected the settlement time. The void ratio at $\mathrm{BH} 2$ was an average of 1 , meaning the material was more sand dominant than that of $\mathrm{BH}$. However, the compressibility test was not proven for the sand layer due to the nonplasticity of the materials to compare the results. Moreover, the hydrodynamic load behavior in deeper water (BH2) also had a higher lateral flow force than in shallow-water conditions in BH3. This is based on Bernoulli's energy equation principle and is accurate for tides in the estuary, which has a slope of bed sediment toward the shallower river mouth. However, an evaluation of the lateral flow force was not considered quantitatively 
in this study, especially the load due to erosion processes that might also be able to produce an axial load influencing the settlement sediment.

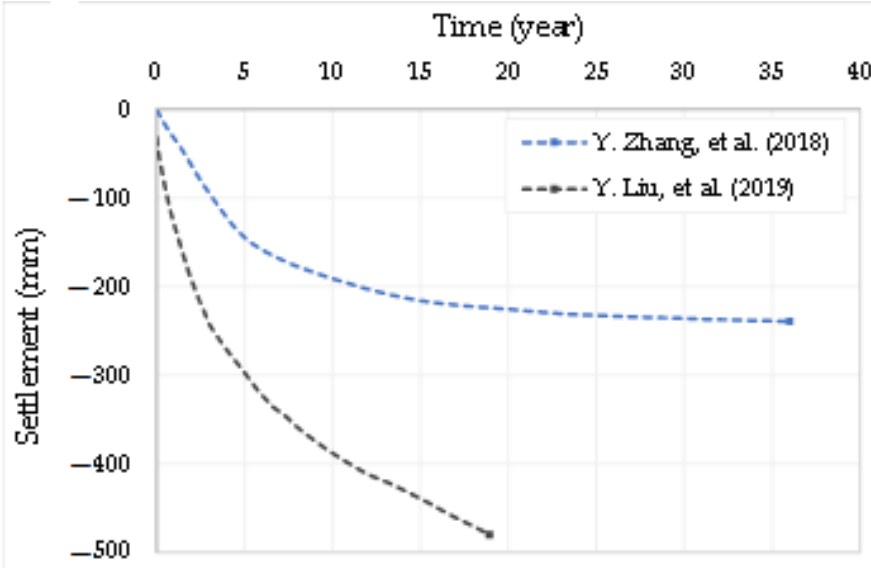

(a)

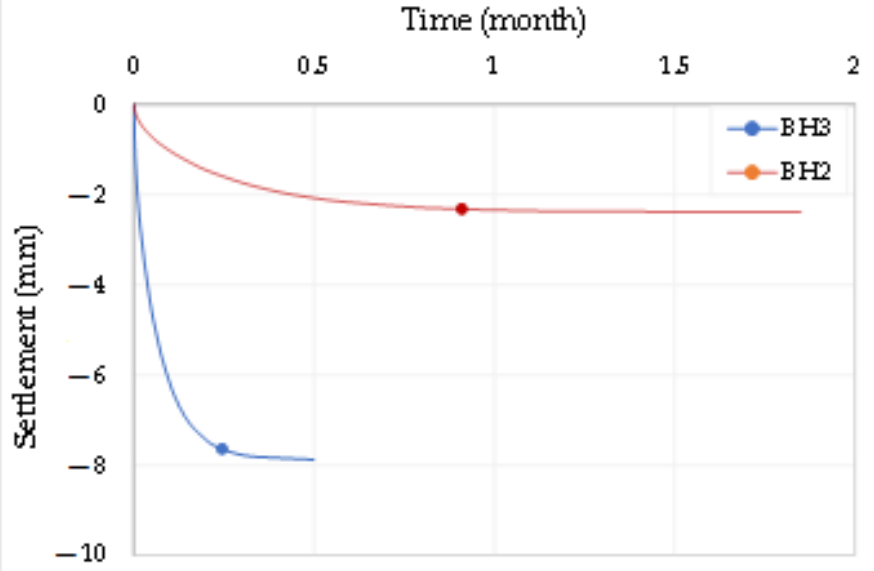

(b)

Figure 13. Comparison of sediment settlement in the previous study on the river delta by Y. Zhang, et al. (2018) and Y. Liu, et al. (2019) (a) and present study at BH2 and BH3 (b).

BH 2

\section{Clay Content (\%) Void ratio $\quad \alpha\left(\mathrm{cm}^{2} / \mathrm{kg}\right)$}

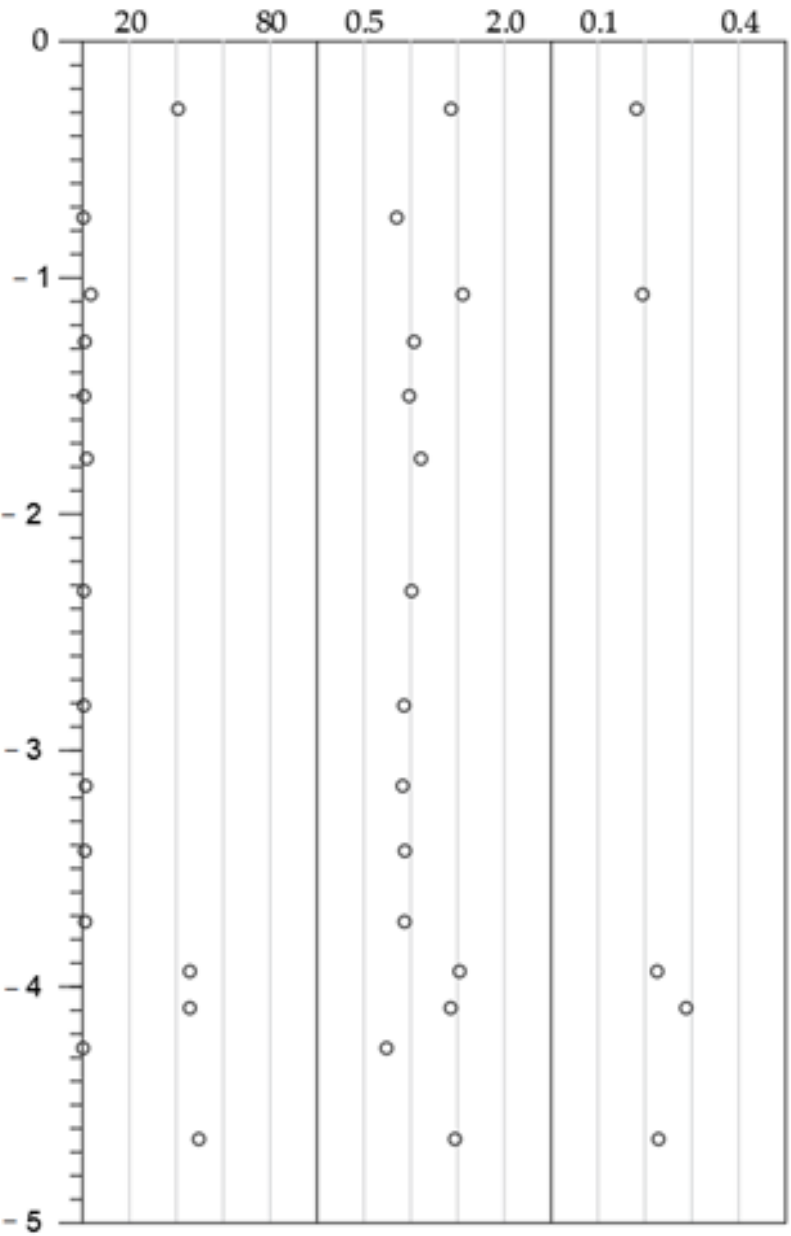

BH 3

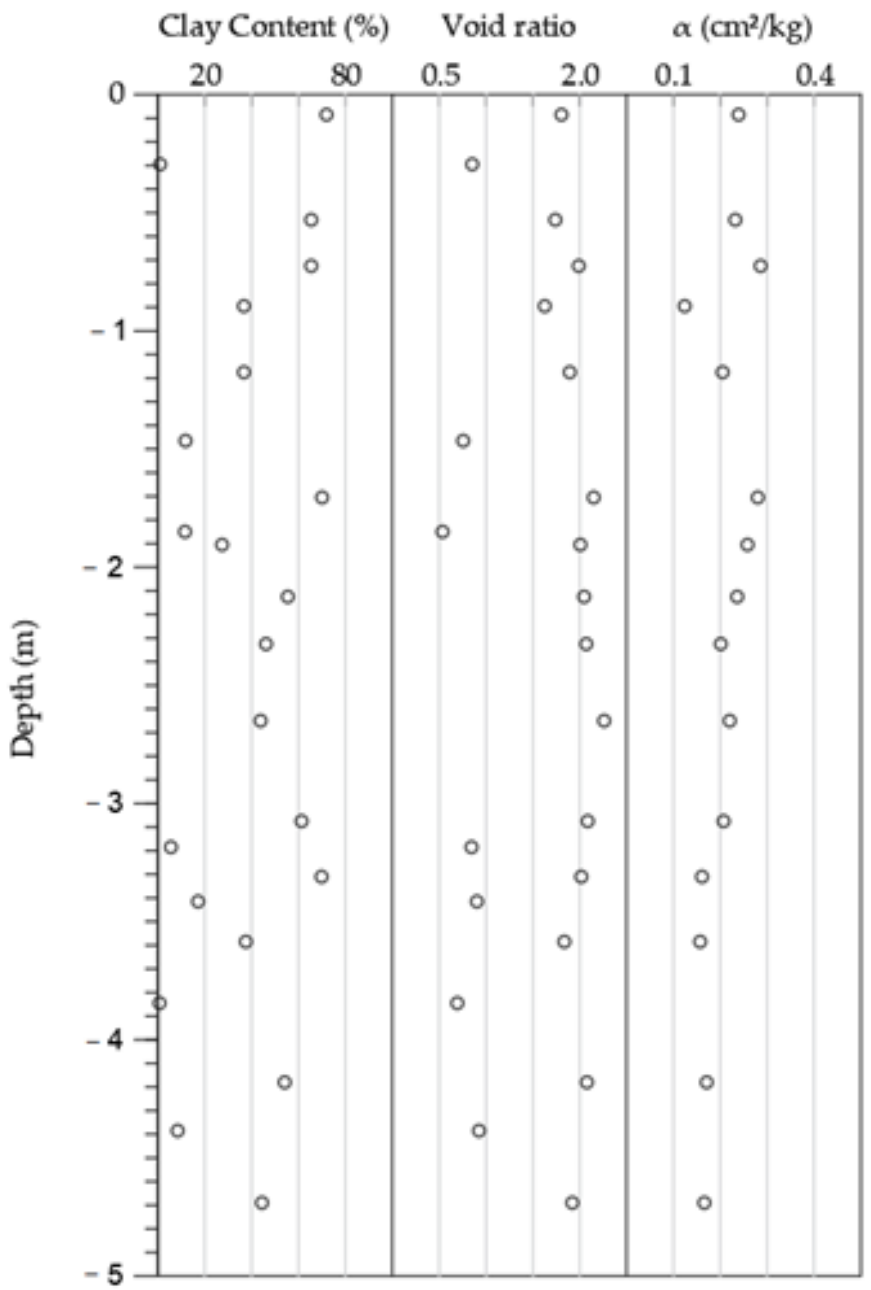

Figure 14. Sediment consolidation parameters consisting of clay content (\%), void ratio, and compressibility coefficient $(\alpha)$ at $\mathrm{BH} 2$ and $\mathrm{BH} 3$. 


\section{Conclusions}

This study identified different geometric conditions considering the high loading pressure. $\mathrm{BH} 2$ was subjected to higher load pressure in the deeper water than $\mathrm{BH} 3$, which was lower. Loading criteria at $\mathrm{BH} 2$ proved that the water level became higher due to channel geometry changes, becoming narrow and branching off, and larger river discharge. While $\mathrm{BH} 3$ was predicted, there was no additional load because of the maximum pressure of flood tide reoccurring in the last simulation. It may be possible that the previous period data at $\mathrm{BH} 2$ had a higher load pressure. Therefore, it would be possible for future research and should be supported by historical data. Sediment layer characteristics in both locations were reviewed against a loading column settled for almost a month and two weeks, respectively, for sediment settlements of more or less than 2 and $8 \mathrm{~mm}$ at adjacent times, i.e., five years for a $10 \mathrm{~cm}$ settlement, but distinct processes. $\mathrm{BH} 2$ was predicted due to the sand distribution being greater than that of soft soils. Likewise, the opposite condition occurred in BH3. The void ratio and compressibility coefficient $(\alpha)$ also affected the settlement time. However, there was no comparison between these parameters because of the nonplastic material in $\mathrm{BH} 2$. The findings reported in this paper can further our understanding of the loading criteria and settlement characteristics of the estuary area.

Author Contributions: Conceptualization, A.P., R.A.A.S., D.D.W., W.W., T.M., and G.T.; methodology, A.P., R.A.A.S., D.D.W., W.W., T.M., G.T., M.A.M., and T.R.S.; software, A.P.; validation, A.P., D.D.W., and M.A.M.; formal analysis, A.P., R.A.A.S., D.D.W., W.W., T.M., G.T., M.A.M., and T.R.S.; investigation, A.P., D.D.W., and M.A.M.; data curation, A.P.; writing-original draft preparation, A.P., R.A.A.S., D.D.W., W.W., T.M., G.T., and M.A.M.; writing-review and editing, A.P., R.A.A.S., D.D.W., W.W., T.M., G.T., and M.A.M.; supervision, R.A.A.S., D.D.W., W.W., T.M., G.T., M.A.M., and T.R.S.; funding acquisition, R.A.A.S. and D.D.W. All authors have read and agreed to the published version of the manuscript.

Funding: This research was funded by the National Academy of Science and Research Grant for Master Program of Education Leading to Doctoral Degree for Excellent Graduates 2015-2019 (PMDSU) grant number 1511/E4.4/2015 from Directorate General of Higher Education-Ministry of Education and Culture.

Institutional Review Board Statement: Not applicable.

Informed Consent Statement: Not applicable.

Data Availability Statement: Not applicable.

Acknowledgments: We thank the Partnerships for Enhanced Engagement in Research (PEER) program to support research and capacity-building activities; and the Ministry of Research, Technology and Higher Education of Indonesia (Ristekdikti) for the research grant through PMDSU Program. The first author also thanks Nila Sutra from Institut Teknologi Sepuluh Nopember, Indonesia, for the help during the paper writing.

Conflicts of Interest: The authors declare no conflict of interest.

\section{References}

1. Teatini, P.; Tosi, L.; Strozzi, T. Quantitative evidence that compaction of Holocene sediments drives the present land subsidence of the Po Delta, Italy. J. Geophys. Res. Solid Earth 2011, 116, 1-10. [CrossRef]

2. Zhang, Y.; Huang, H.; Liu, Y.; Liu, Y.; Bi, H. Spatial and temporal variations in subsidence due to the natural consolidation and compaction of sediment in the yellow river delta, china. Mar. Georesources Geotechnol 2019, 37, 152-163. [CrossRef]

3. Siddiqui, N.A.; Rahman, A.H.A.; Sum, C.W.; Yusoff, W.I.W.; bin Ismail, M.S. Shallow-marine Sandstone Reservoirs, Depositional Environments, Stratigraphic Characteristics and Facies Model: A Review. J. Appl. Sci. 2017, 17, 212-237. [CrossRef]

4. Wolanski, E.; Huan, N.N.; Dao, L.T.; Nhan, N.H.; Thuy, N.N. Fine-sediment dynamics in the Mekong River Estuary, Vietnam. Estuar. Coast. Shelf Sci. 1996, 43, 565-582. [CrossRef]

5. Zhang, Y.; Huang, H.; Liu, Y.; Liu, Y. Self-weight consolidation and compaction of sediment in the Yellow River Delta, China. Phys. Geogr. 2018, 39, 84-98. [CrossRef]

6. Liu, Y.; Du, T.; Huang, H.; Liu, Y.; Zhang, Y. Estimation of sediment compaction and its relationship with river channel distributions in the Yellow River delta, China. Catena 2019, 182, 104113. [CrossRef] 
7. Satrya, T.R.; Soemitro, R.A.A.; Maulana, M.A.; Warnana, D.D.; Soetanto, R. Assessment of Infrastructures Assets Induced by Water Level Fluctuation along the Bengawan Solo River. J. Infrastruct. Facil. Asset Manag. 2019, 1, 105-112. [CrossRef]

8. Palamenghi, L. Tectonic and Sea Level Control on the Transport and Depositional Processes in a Siliciclastic Sedimentary Basin. Insights from the Ganges-Brahmaputra Delta, Bengal Basin, Bangladesh. Doctoral Thesis, University of Bremen, Bremen, Germany, 30 April 2012. Available online: https:/ / core.ac.uk/download/pdf/46919574.pdf (accessed on 15 February 2021).

9. Becker, R.H.; Sultan, M. Land subsidence in the Nile Delta: Inferences from radar interferometry. Holocene 2009, 19, 949-954. [CrossRef]

10. Belperio, A.P. Land subsidence and sea level rise in the port adelaide estuary: Implications for monitoring the greenhouse effect. Aust. J. Earth Sci. 1993, 40, 359-368. [CrossRef]

11. Featherstone, W.E.; Filmer, M.S.; Penna, N.T.; Morgan, L.M.; Schenk, A. Anthropogenic land subsidence in the Perth Basin: Challenges for its retrospective geodetic detection. J. R. Soc. West. Aust. 2012, 95, 53-62.

12. de Vries, K. Land subsidence and hydrodybanic compaction of sedimentary basins. Hydrol. Earth Syst. Sci. 1998, 2, 159-171. Available online: https://www.hydrol-earth-syst-sci.net/2/159/1998/hess-2-159-1998.pdf (accessed on 15 February 2021). [CrossRef]

13. Kooi, H. Land subsidence due to compaction in the coastal area of The Netherlands: The role of lateral fluid flow and constraints from well-log data. Glob. Planet. Change 2000, 27, 207-222. [CrossRef]

14. Meckel, T.A.; ten Brink, U.S.; Williams, S.J. Current subsidence rates due to compaction of Holocene sediments in southern Louisiana. Geophys. Res. Lett. 2006, 33, 1-5. [CrossRef]

15. Changxing, S.; Dian, Z.; Lianyuan, Y.; Bingyuan, L.; Zulu, Z.; Ouyang, Z. Land subsidence as a result of sediment consolidation in the yellow river delta. J. Coast. Res. 2007, 23, 173-181. [CrossRef]

16. Patriadi, A.; Soemitro, R.A.A.; Warnana, D.D.; Wardoyo, W.; Mukunoki, T.; Tsujimoto, G. The Influence of Sembayat Weir on Sediment Transport Rate in the Estuary of Bengawan Solo River, Indonesia. Int. J. Geomate 2021, 20, 35-43. [CrossRef]

17. Brunner, G.W.; United States Army Corps of Engineers; Institute for Water Resources (U.S.); Hidrologic Engineering Center (U.S.). HEC-RAS River Analisys Systems User's Manual; US Army Corps of Engineers, Institute for Water Resources, Hydrologic Engineering Center: Davis, CA, USA, 2016; p. 962.

18. Seo, H.J.; Cho, M.; Yoon, H.D. Data-driven analysis of stratified flow effect on suspended sediment concentration in an estuary. J. Mar. Sci. Eng. 2020, 8, 606. [CrossRef]

19. Te, C.V. Open-Channel Hydraulics: International Student Ed.; McGraw-Hill Book Company, Inc.: New York, NY, USA, 1959.

20. Gill, A.E. Atmosphere-Ocean Dynamics: Int. Geophysics Series; Academic Press: San Diego, CA, USA, 1982 ; Volume 30.

21. Wright, A.E. Metamorphic facies. In Petrology. Encyclopedia of Earth Science; Springer: Boston, MA, USA, 1989. [CrossRef]

22. Das, B.M. Principles of Geotechnical Engineering, 7th ed.; Cengage Learning: Stamford, CT, USA, 2010.

23. Perillo, G.M.E. Geomorphology and Sedimentology of Estuaries: An Intrduction. In Developments in Sedimentology; Elsevier: Amsterdam, The Netherlands, 1995; Volume 53, pp. 1-16.

24. EBMEG (Editorial Board of Manual of Engineering Geology). Manual of Engineering Geology, 2nd ed.; Chinese Architectural Industry Press: Beijing, China, 1982. (In Chinese)

25. Ji, U.; Julien, P.Y.; Park, S.K. Sediment flushing at the nakdong river estuary barrage. J. Hydraul. Eng. 2011, 137, 1522-1535. [CrossRef]

26. Franz, G.; Pinto, L.; Ascione, I.; Mateus, M.; Fernandes, R.; Leitão, P.; Neves, R. Modelling of cohesive sediment dynamics in tidal estuarine systems: Case study of Tagus estuary, Portugal. Estuar. Coast. Shelf Sci. 2014, 151, 34-44. [CrossRef]

27. Soemitro, R.A.A.; Adriati, F.; Warnana, D.D.; Mukunoki, T.; Soetanto, R.; Maulana, M.A. Sediment consolidation in ephemeral river: The effect of applied loading on soil properties and dredging method selection. Int. J. River Basin Manag. 2020, 1-10. [CrossRef] 